\title{
An assessment of radial haemolysis in the detection of rubella antibody
}

\author{
B. GEE, BARBARA E. JORDAN, AND P. R. MORTIMER \\ From the Public Health Laboratory, Coventry and Warwickshire Hospital, Coventry CVI 4FH, UK
}

SUMMARY The results obtained by radial haemolysis in the detection of antibodies to rubella virus compared well with those obtained by haemagglutination inhibition. Radial haemolysis is unaffected by non-specific inhibitors. The sera do not therefore require pretreatment and the results are less equivocal. Radial haemolysis appears to be as sensitive as immunofluorescence and floatation centrifugation. It is possible to examine large numbers of sera with a considerable saving of time compared with the traditional haemagglutination technique. Rheumatoid factor may cause interference in radial haemolysis. Immune sera may be recorded as non-immune. This interference can be removed by 2 -mercaptoethanol or reduced by heating sera at $60^{\circ} \mathrm{C}$ for 20 minutes.

Antibodies to rubella virus are most commonly demonstrated using the haemagglutination inhibition (HI) test. This test is relatively simple but involves pretreatment of the sera to remove nonspecific inhibitors and absorption to remove agglutinins to the erythrocytes. It is subject to some variability both within and between laboratories and the whole procedure must be carefully controlled to minimise such variation. Although the test is sensitive some difficulty arises in interpreting the significance of low HI titres because of the possibility of interference from residual nonspecific inhibitors.

Schild et al. (1975) described the use of radial haemolysis (RH) for influenza virus. Its application to the detection of antibodies to rubella virus has been described recently by Strannegărd et al. (1975), Skaug et al. (1975), and Grillner and Strannegărd (1976). It depends on the lysis of erythrocytes coated with haemagglutinin by complement in the presence of specific antibody. The method they described was simple to perform and both sensitive and reproducible. It should therefore be suitable for the screening of large numbers of sera.

In this paper we compare the rubella antibody results obtained by the HI and RH techniques.

\section{Material and methods}

Altogether 1182 sera were examined: 1089 were routine sera submitted to the laboratory for rubella estimations (during 1976-77) and were mainly from

Received for publication 29 June 1977 women of childbearing age; 8 were sera found to be anticomplementary in other tests; 32 were sera found to contain rheumatoid factor by the latex fixation test; and 53 sera had low titres when examined for rubella $\mathrm{HI}$ antibodies as part of a collaborative Public Health Laboratory Service (PHLS) study.

\section{HAEMAGGLUTINATION INHIBITION} TECHNIQUE

The HI test was carried out according to the method described by Stewart et al. (1967). Sera were pretreated with $25 \%$ kaolin to remove nonspecific inhibitors. Erythrocytes from day-old chick cells were used as the indicator cells and the microtitre (Dynatech) system was used. Titres of $<1 / 16$ were regarded as non-immune.

RADIAL HAEMOLYSIS TECHNIQUE

Sheep cells, trypsinised human ' $O$ ' cells (Quirin et al., 1972), and day-old chick cells were all found to give reactions in radial haemolysis. Day-old chick cells gave the strongest reactions and were used throughout this investigation.

The chick cells were washed in veronal buffer, $\mathrm{pH}$ 7.2 (Oxoid BR 16), and their concentration was adjusted to $8 \%$. Rubella haemagglutinin (HA) was diluted in veronal buffer to give a concentration of 8 HAD $_{50}$. One millilitre of $8 \%$ chick cells was added to $9 \mathrm{ml}$ of HA; after mixing this was allowed to stand at room temperature for 30 minutes, washed once in veronal buffer, and finally resuspended in veronal buffer to the same volume.

Of these sensitised cells, $7 \mathrm{ml}$, warmed to $37^{\circ} \mathrm{C}$, 
were mixed with $6.4 \mathrm{ml}$ of $1.5 \%$ agarose (BDH) in veronal buffer, melted, and precooled to $56^{\circ} \mathrm{C}$. This was poured into a $100 \mathrm{~mm}$ square petri dish on a level table. After solidifying $2.5 \mathrm{~mm}$ wells were punched 15 mm apart using a template. The plates were kept at $4^{\circ} \mathrm{C}$ until used. Control plates containing unsensitised chick cells were prepared in a similar manner.

The sera were inactivated at $56^{\circ} \mathrm{C}$ for 30 minutes and $5 \mu \mathrm{l}$ of each serum was added to wells of both control and test plates. Strongly positive, weakly positive, and negative control sera were included with each batch of tests.

The plates were incubated at $4^{\circ} \mathrm{C}$ for 18 hours and then placed at $37^{\circ} \mathrm{C}$. After 30 minutes each plate was flooded with $5 \mathrm{ml}$ of a $1 / 5$ dilution of reconstituted freeze-dried complement (Wellcome Reagents). The haemolysis was allowed to develop for 4 hours at $37^{\circ} \mathrm{C}$. The plates were illuminated by oblique light from below using a Partigen Viewer (Hoechst) and the zones were measured with a transparent scale.

\section{MERCAPTOETHANOL TREATMENT}

Selected sera were treated with 2-mercaptoethanol at a final concentration of $0.1 \mathrm{~mol} / \mathrm{l}$. In addition, plates containing 2-mercaptoethanol at concentrations of $0.1 \mathrm{~mol} / 1,0.05 \mathrm{~mol} / 1$, and $0.025 \mathrm{~mol} / 1$ were prepared.

\section{FLOATATION CENTRIFUGATION AND IMMUNOFLUORESCENCE}

The floatation centrifugation and immunofluorescence estimations were performed as part of a PHLS collaborative study by Dr J. R. Pattison (London Hospital Medical College) and Dr J. E. CradockWatson (Public Health Laboratory, Manchester) respectively.

\section{Results}

CORRELATION BETWEEN HI TITRES AND

\section{ZONES OF HAEMOLYSIS}

Dilutions of a single high-titre serum were tested by RH in triplicate. The diameters of the zones of haemolysis were plotted against the HI antibody titre (Fig. 1). Dilutions containing antibody at a concentration equivalent to an $\mathrm{HI}$ titre of $1 / 4$ gave a measurable zone.

The HI titres, the mean diameters and the number of sera corresponding to them are recorded in Figure 2.

\section{RADIAL HAEMOLYSIS AS AN INDICATOR OF IMMUNITY}

Table 1 shows the results obtained in $\mathrm{RH}$ with sera which gave low HI titres. Sera giving a measurable zone were recorded as immune by RH. Table 2 shows the results obtained with low-titre sera collected during the PHLS collaborative study. The HI

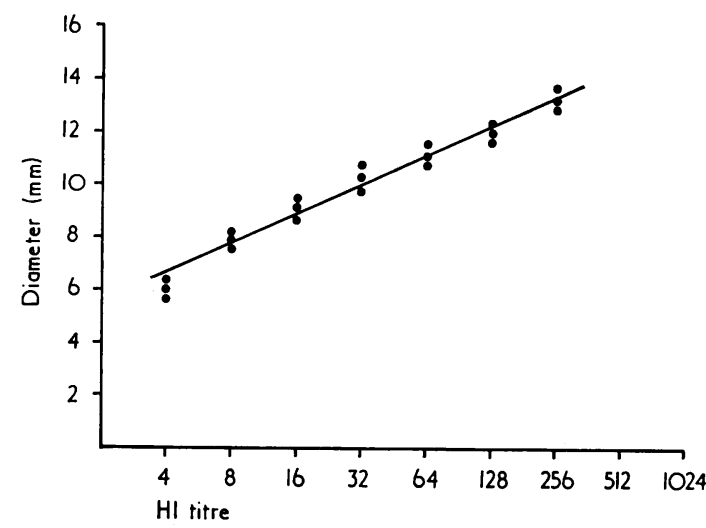

Fig. 1 Correlation between HI antibody concentration and $R H$ diameter in a series of dilutions of a single serum.

titres in this survey were determined by $\mathrm{Dr}$ J. R. Pattison.

EFFECT OF ANTICOMPLEMENTARY SERA No effect was found on the size of zones produced by the eight anticomplementary sera.

EFFECT OF RHEUMATOID FACTOR Of 32 sera containing rheumatoid factor examined by both the HI and RH techniques, one had no detectable antibody by $\mathrm{HI}$ while nine had no detectable antibody by RH. The sera-giving zones had an inner

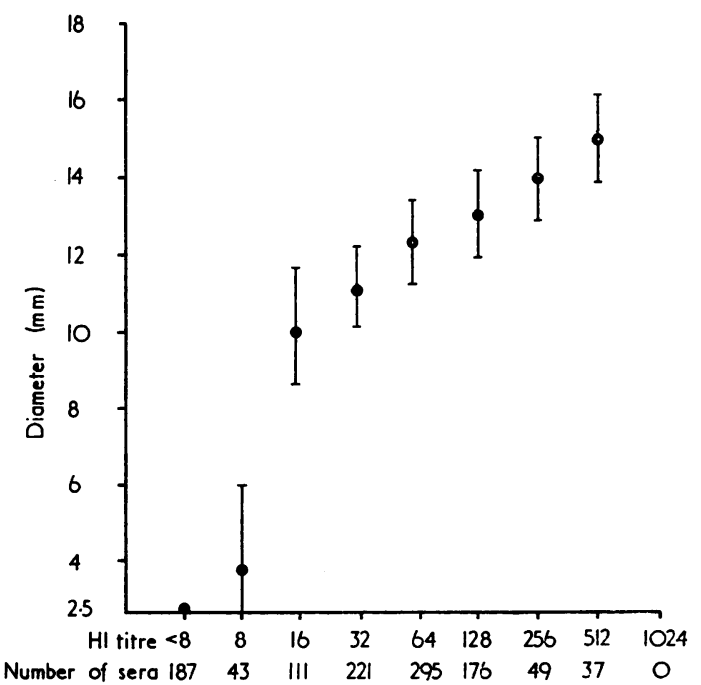

Fig. 2 Correlation between $\mathrm{HI}$ and $\mathrm{RH}$ when 1089 sera were examined. Mean values, standard deviations, and number of sera for each HI litre are given. 
Table 1 Comparison of $R H$ and $H I$ with low-titre sera

\begin{tabular}{lccc}
\hline No. of specimens & HI titre & RH non-immune & RH immune \\
\hline 187 & $<8$ & 187 & 0 \\
43 & 8 & 33 & 10 \\
111 & 16 & 1 & 110 \\
\hline
\end{tabular}

Table 2 Detection of rubella antibody by HI, immunofluorescence, floatation centrifugation, and RH (from PHLS collaborative study)

\begin{tabular}{|c|c|c|c|c|c|c|c|}
\hline \multirow[t]{2}{*}{ No. of specimens } & \multirow[t]{2}{*}{ HI titre } & \multicolumn{2}{|c|}{ Immunofluorescence estimation } & \multicolumn{2}{|c|}{ Floatation centrifugation } & \multicolumn{2}{|l|}{$R H$} \\
\hline & & + & - & + & - & + & - \\
\hline $\begin{array}{r}23 \\
8 \\
22\end{array}$ & $\begin{array}{r}<8 \\
8 \\
16\end{array}$ & $\begin{array}{r}2 \\
8 \\
22\end{array}$ & $\begin{array}{r}21 \\
0 \\
0\end{array}$ & $\begin{array}{r}2 \\
8 \\
22\end{array}$ & $\begin{array}{r}21 \\
0 \\
0\end{array}$ & $\begin{array}{r}2 \\
8 \\
22\end{array}$ & $\begin{array}{r}21 \\
0 \\
0\end{array}$ \\
\hline
\end{tabular}

zone of incomplete or non-lysis surrounded by a ring of complete lysis.

Six of these non-reacting sera were treated with 2mercaptoethanol for 1 hour after which all six gave clear zones of haemolysis. The incorporation of 2mercaptoethanol in the agar at concentrations between 0.1 and $0.025 \mathrm{~mol} / 1$ was unsuccessful because it appeared to interfere with the action of complement by preventing lysis of sensitised chick cells.

Heating the sera at $60^{\circ} \mathrm{C}$ for 20 minutes was found to reduce this interference but unfortunately heating for longer than 20 minutes reduced the zones given by low-titre sera. Three out of eight sera immune by HI but non-immune by RH became reactive when inactivated at $60^{\circ} \mathrm{C}$ for 20 minutes instead of at $56^{\circ} \mathrm{C}$ for 30 minutes.

INCIDENCE OF NONSPECIFIC LYSIS

Four of the 1089 sera gave zones of haemolysis with the unsensitised cells in the control plates.

\section{Discussion}

Radial haemolysis lends itself readily to the examination of large numbers of sera. It requires only small quantities of serum which do not require pretreatment to remove nonspecific inhibitors or naturally occurring agglutinins. The method is not uneconomi$\mathrm{cal}$ in reagents. One millilitre of rubella $\mathrm{HA}$ antigen and $5 \mathrm{ml}$ of complement are sufficient for 90 sera. Fewer red cells are required than for HI because preabsorption is unnecessary.

Good correlation was found between the $\mathrm{HI}$ titres and zone diameters (Figs 1 and 2), confirming the observations made by Strannegărd et al. (1975) and Skaug et al. (1975), and the RH results were reproducible and unequivocal. Low titres obtained in the HI test are difficult to interpret because of the possible interference of residual nonspecific inhibitor whereas RH is unaffected by nonspecific inhibitor and any zone produced is an indication of specific antibody. In this respect RH appears to be as effective as indirect immunofluorescence and floatation centrifugation in determining immune status. The test is, however, a good deal easier to perform and considerable time can be saved when large numbers of sera are examined.

Unfortunately, rheumatoid factor may interfere in RH. In the 32 sera containing rheumatoid factor eight would have been incorrectly regarded as nonimmune. Evidence of rheumatoid factor interference was not found in the 1089 routine sera examined. Of the 221 found to be non-immune by RH, 187 had an HI titre of $<1 / 8,33$ were $1 / 8$, and 1 was $1 / 16$. Titres of $1 / 8$ and $<1 / 8$ are regarded as nonimmune in this laboratory. The serum with a titre of $1 / 16$ did not contain rheumatoid factor and repeat examinations of this serum by HI gave lower titres, suggesting that the result was due to nonspecific inhibitors. Skaug et al. (1975) reported one serum out of 200 tested which showed no antibody by RH but was immune by HI. They suggested that this was due to a high content of nonspecific inhibitor but did not record its rheumatoid activity. It is possible, though we have not observed it, that a pair of sera taken from a patient with rheumatoid arthritis could show an apparent rise in antibody level which was due to a change in titre of the rheumatoid factor and not associated with rubella infection. Equally, a rising rubella antibody level might be completely masked by rheumatoid factor.

2-Mercaptoethanol was effective in removing the interfering factor. It is doubtful whether pretreatment of all sera with 2-mercaptoethanol can be justified. Heating at $60^{\circ} \mathrm{C}$ for 20 minutes reduced but did not eliminate the interference but as it involves no extra effort it might be wise to inactivate all sera in this way.

The interfering effect of rheumatoid factor in sera 
being investigated to determine individuals' immune status is unlikely to be a serious problem although reporting immune individuals as non-immune may expose them to unnecessary anxiety or result in unnecessary immunisation. Reservations must be made about the suitability of the method for patients who are possible cases and contacts of rubella infection until a satisfactory method of dealing with rheumatoid factor is found.

We thank Dr J. E. Cradock-Watson and Dr J. R. Pattison for permission to quote the results of their immunofluorescence and floatation centrifugation studies.

\section{References}

Grillner, L., and Strannegărd, O. (1976). Evaluation of the haemolysis in-gel test for the screening of rubella immunity and the demonstration of recent infection. Journal of Clinical Microbiology, 3, 86-90.
Quirin, E. P., Nelson, D. B., and Inhorn, S. L. (1972). Use of trypsin modified human erythrocytes in rubella haemagglutination-inhibition testing. Applied Microbiology, 24, 353-357.

Schild, G. C., Periera, M. S., and Chakraverty, P. (1975). Single-radial-haemolysis: a new method for the assay of antibody to influenza haemagglutinin. Applications for diagnosis and seroepidemiologic surveillance of influenza. Bulletin of the World Health Organization, 52, 43-50.

Skaug, K., Ørstavik, I., and Ulstrup, J. C. (1975). Application of the passive haemolysis test for the determination of rubella virus antibodies. Acta Pathologica et Microbiologica Scandinavica, Section B, 83, 367-372.

Stewart, G. L., Parkman, P. D., Hopps, H. E., Douglas, R. D., Hamilton, J. P., and Meyer, H. M. Jr. (1967). Rubella virus haemagglutination inhibition test. New Engl. J. Med., 276 554-557.

Strannegărd, O., Grillner, L., and Lindberg, I. M. (1975). Haemolysis in-gel test for the demonstration of antibodies to rubella virus. Journal of Clinical Microbiology, 1, 491-494. 